\title{
CHANGES IN LYMPHATIC ORGANS OF LAYER CHICKENS FOLLOWING VACCINATION AGAINST MAREK'S DISEASE: HISTOLOGICAL AND STEREOLOGICAL ANALYSIS
}

\author{
MILJKOVIĆ BILJANA*, RAKIN ANA**, AŠANIN RUŽICA***, DIMITRIJEVIĆ LJILJANA** \\ and MIĆIĆ MILEVA**** \\ *Institute of Veterinary Medicine of Serbia, \\ **Immunology Research Center "Branislav Jankovic", Institute of Immunology and Virology "Torlak", \\ ${ }^{* * *}$ Faculty of Veterinary Medicine, \\ $\star \star \star \star$ Institute for Medical Research, University of Belgrade \\ (Received 13. October 2007)
}

The aim of this study was to investigate histomorphometrical characteristics of the thymus, bursa of Fabricius and spleen in the chickens vaccinated with a vaccine against Marek's disease. For this purpose, we used newly hatched chickens of the light hybrid line, obtained from a local hatchery. The chickens were vaccinated on the 5th day after hatching with a bivalent cell-associated Marek's disease vaccine (PFU-2000 per dose). On day 13 both vaccinated chickens and unvaccinated controls were sacrificed, and thymus, bursa and spleen were removed and processed for light microscopy. The serial tissue sections, hematoxylin-eosine stained, were used for histomorphometric analysis. Vaccination against Marek's disease decreased the relative mass of the lymphoid organs, and caused significant damage of the thymus and spleen in experimental chicken. In addition, vaccination, similar to Marek's disease virus, induced morphometric changes in the lymphoid organs. Namely, it significantly decreased the diameter and volume of lymphoid follicles, volume of follicular medulla and number of cells in the follicular cortex in the bursa of Fabricius. In the thymus, vaccination reduced the thymus volume and the absolute number of thymocytes. However, vaccination against Marek's disease caused an increase in the diameter, number and volume of lymphoid follicles in the spleen.

The present data suggest that vaccination against Marek's disease was able to induce the immune response in processed organs, although it reduced the mass and number of lymphocytes in the major lymphoid organs.

Key words: bursa of Fabricius, Marek's disease, morphometry, spleen, thymus, vaccine 


\section{INTRODUCTION}

Marek's disease (MD) is a contagious disorder of chickens, worldwide spread, caused by Marek's disease virus (MDV), an Alpha herpes virus that induces $\mathrm{T}$ cell lymphomas, polyneuritis, immunosuppression and rarely atherosclerosis (Churchill and Biggs, 1967; Calnek, 2001; Brown et al., 2006). The outcome of infection is dependent on the virus oncogenecity and the genetic resistance of chicken. Numerous studies have demonstrated the existence of MDV strains of different pathogenicity, ranging from a naturally avirulent chicken herpes virus and a naturally avirulent turkey herpes virus (HVT) (serotypes 2 and 3 ), to highly virulent strains (serotype 1) in poultry populations (Witter, 1998). Genetic resistance has been linked, partly, to class I major histocompatibility complex (MHC) antigens (Powell and Lombardini, 1986). In addition, the incidence of Marek's disease is influenced by factors associated with environmental conditions (Witter et al., 1984).

Although natural infection with MDV occurs by inhalation of cell-free MDV in feather dander (Beasley et al., 1970), the respiratory tract does not appear to be an early site of virus replication (Adidinger and Calnek, 1973). Marek's disease virus enters the primary lymphatic organs via macrophages (Barrow et al., 2003). The virus is usually detectable on the 4th day post infection by the viral internal antigens and virus isolation occours in the spleen, bursa of Fabricius and thymus (Calnek et al., 1984; Islam et al., 2002). Mareks' disease is characterized by: (1) an early cytolytic infection of $B$ lymphocytes, and a small percentage of activated $T$ lymphocytes; (2) latent infection of both B and T lymphocytes; (3) late cytolytic infection of mainly T lymphocytes; and (4) transformation of lymphatic cells (T cells), leading to lymphoid tumor formation and death (Venugopal and Payne, 1995; Calnek et al., 1998; Calnek, 2001).

Having in mind that MD causes severe death losses and condemnation of the affected flocks, prevention of MD can be accomplished by monovalent, polyvalent or recombinant vaccines. Previously published reports indicate that different vaccine types have different efficiency on the immune system of chickens (Lee et al., 1978; Calnek et al., 1979; Friedman et al., 1992; Fynan et al., 1995; Mićić et al., 2000; Tischer et al., 2002). Cell-mediated immunity, in particular the activity of cytotoxic T lymphocytes (mainly CD8+ cells), has an important role in the vaccinal protective mechanism against MD lymphoma (Omar and Schat, 1996). Vaccination is usually protective against the development of clinical manifestations of MD, but does not prevent MDV infection (Purchase et al., 1971; Lee et al., 1999; Witter, 2001; Islam et al., 2001; 2002).

However, fast changes of Marek's disease virus genome towards greater virulence may explain increased poultry losses from MD even in vaccinated flocks (Witter, 1998). Vaccine efficacy might be affect by many factors, such as the B haplotype (Bacon and Witter, 1993, 1994a, b), maternal antibodies (Witter and Lee, 1984; Witter et al., 1995; Sonoda et al., 2000), vaccine dose and so on.

Having in mind the data above, the aim of this study was to identify and quantify changes in the lymphatic organs of vaccinated chickens, by histological and stereological methods. 


\section{MATERIALS AND METHODS}

\section{Experimental animals and tissue preparation}

Newly hatched chicks of light hybrid line were obtained from a local hatchery. They were given commercial feed and water ad libitum. The chicks were divided randomly into two groups. The first group was vaccinated 5 days after hatching with a bivalent cell-associated Marek's disease vaccine (Bio Marek bivalent), containing et least 2000 plaque forming units of turkey herpes virus FC126 and chicken herpes virus HPRS-16 per dose. The second group of unvaccinated chicks, was used as the control. On day 13 after hatching, ten chicks from each group were sacrificed and lymphatic organs (bursas, thymuses and spleens) were removed for further analysis. The chicks and matching bursas, thymuses and spleens were weighted. The removed organs were fixed in Bouin's solution for $12 \mathrm{~h}$. Paraffin sequentional serial sections (5 $\mu \mathrm{m}$ thickness) of the bursa, thymus and spleen were stained with hematoxylin-eosin. We used the multipurpose test system M42 for morphometric measurements.

\section{Morphometric measurements}

Histoquantitative studies were performed using the multipurpose test system M42 (Weibel, 1979). Each $10^{\text {th }}$ section was analyzed under a Reichert Biovar (Austria) microscope with an eyepiece fitted with Weibel's M 42 test system. The test area was always chosen at random, and the size of the final sample was calculated for each parameter separately to provide results within the confidence interval of $95 \%$ percent.

Volume density $(\mathrm{Vv})$ of the thymic cortex and medulla, bursal follicles, follicular cortex and medulla, and lymphocytic follicles in the spleen were determined under a magnification x 6.3, using a point-counting method (Weibel, 1979), and calculated according to the equation:

$$
\mathrm{Vv}=\mathrm{Pf} / \mathrm{Pt}
$$

Where $\mathrm{Pf}=$ the number of test points falling on the analyzed structure; $\mathrm{Pt}$ the total number of test points (Kališnik, 1985).

Absolute values of examined structures were calculated from their volume density and absolute volume of the whole organ.

Numerical density of the lymphocytic follicles in the bursa and spleen, as well as lymphocytes in the thymic compartments and bursal lymphocytic follicles per volume unit were calculated according to the following equation:

$$
\mathrm{Nv}=\mathrm{NA} /(\mathrm{D}+\mathrm{Go})
$$

The number of follicles/lymphocytes per surface unit of the test area (NA) was obtained from the relationship between the number of follicles/lymphocytes per test area $(\mathrm{N})$ and the size of the test area (At).

The mean diameter (D) of the follicles/lymphocytes represents the relationship between volume density (Vv) and surface density (Sv), where Sv represents the relationship between the number of intersections of the test lines 
with the follicles/plasma membrane of lymphocytes and the total length of the test line (Kališnik, 1985).

Depth sharpness (Go) was estimated from the light wavelength (I), coefficient of diffraction of the immersion oil (n) and numerical aperture of the objective lens $(\mathrm{Na})$.

The total number of the thymic and bursal thymocytes/lymphocytes was calculated from NV of thymocytes/lymphocytes in the thymic/bursal compartments and absolute volume of these compartments.

\section{Statistical analysis}

All results are expressed as mean $\pm \mathrm{SD}$. Comparisons among groups were conducted by analysis of variance (ANOVA) test. In all cases, Scheffe test was used as a post hoc analysis. The level of significance was considered at $p<0.05$.

\section{RESULTS}

\section{Body and organ weight}

The results of this study showed that the bivalent vaccine against Marek's disease significantly decreases the relative mass of the thymus $(p<0.001)$, bursa of Fabricius $(p<0.05)$ and spleen $(p<0.01)$ compared to corresponding controls (Figure 1), while body weight remained unchanged (Figure 2). A significant volume decrease of the thymus $(p<0.001)$, bursa of Fabricius $(p<0.05)$ and spleen $(p<0.01)$, in the vaccinated chicken group, was observed, as well (Figure 1). Calculation of the lymphatic organs body index (relationship between the relative weight of the bursa/thymus/spleen in vaccinated and control chickens) revealed significant damage of the thymus and spleen in the vaccinated chicks. However, the decrease of the bursa body index was not significant (Figure 1).

\section{Histological and quantitative analysis}

Bursa of Fabricius

Histological analysis, done by light microscopy, revealed that the size of bursal plicae did not change in the chicks vaccinated against Marek's disease. The bursae of vaccinated birds contained follicles distinguished by their size and the apparent cortical and medullar structure. In addition, within the bursal plicae an increased visibility of the stroma was noted (Figure 3a). In the lymphocytic follicles the reduced number of lymphocytic cells in the follicular cortex, and enlarged density of cells in the follicular medulla, was evident (Figure $3 \mathrm{~b}$ ). Stereological analysis confirmed that vaccination induces a significant decrease of lymphocytic follicles diameter and volume, volume of the follicular medulla and number of cells in the follicular cortex. On the other hand, vaccination against Marek's disease raises the number of lymphocytic cells in the follicular medulla, number of lymphocytic follicles per unit area, as well as their absolute number. Likewise, vaccination alters the relationship between follicular cortex and medulla (Table 1). 
Acta Veterinaria (Beograd), Vol. 58. No. 1, 3-16, 2008.

Miljković Biljana et al: Changes in lymphatic organs of layer chickens following

vaccination against Marek's disease: histological and stereological analysis

$\square$ control

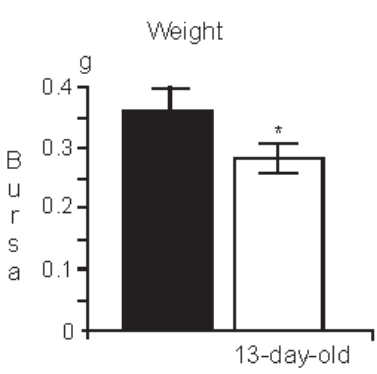

a control

$\square$ vaccined
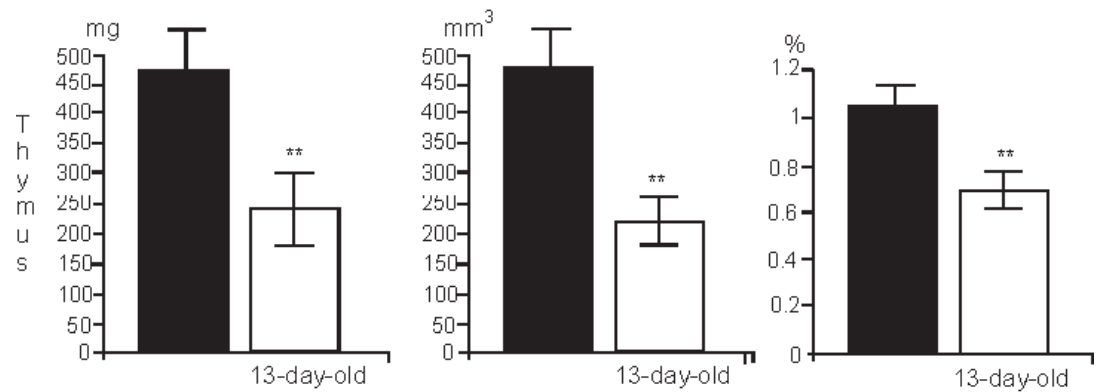

Index of damage

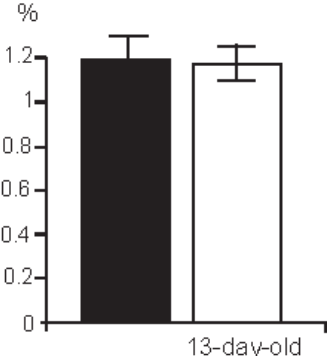

3-day-0ld

control

$\square$ vaccined
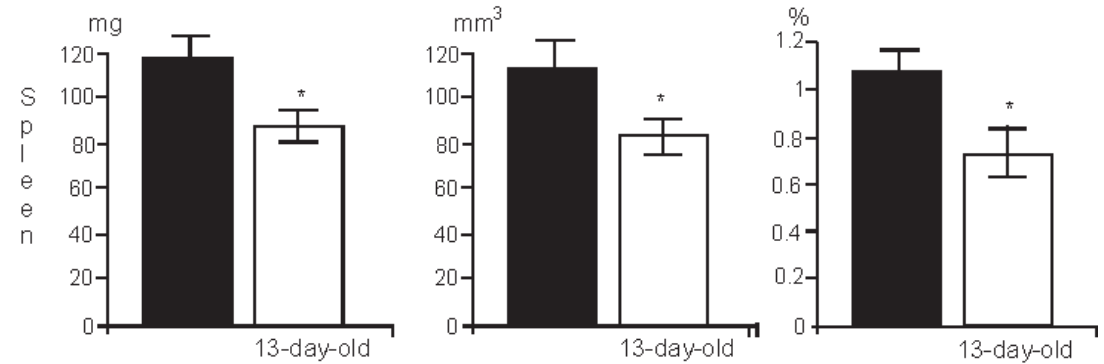

Figure 1. Changes of stereological parameters are shown as graphics: weights, volumes and index of damage of the lympatic organs (bursae, thymus, spleen) in the control and vaccinated chickens. Values represent mean \pm S.D. ${ }^{*} p<0.01 ;{ }^{*} p<0.05$; vs. control 

vaccination against Marek's disease: histological and stereological analysis

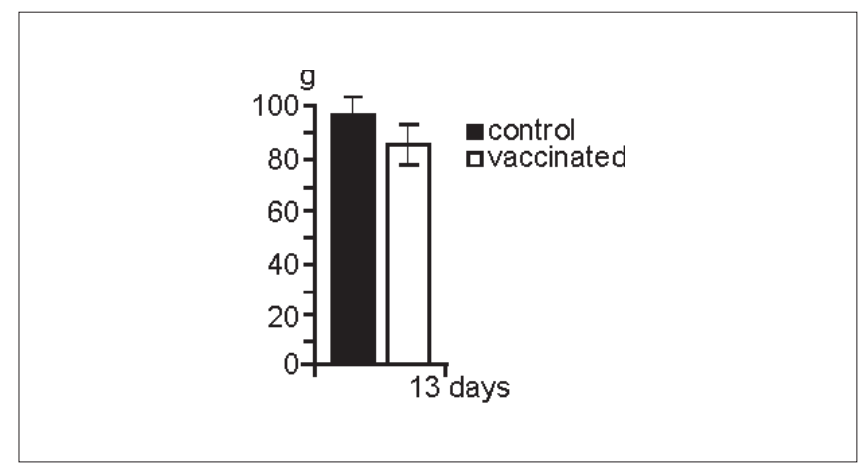

Figure 2. Body weight of the control and vaccinated chickens

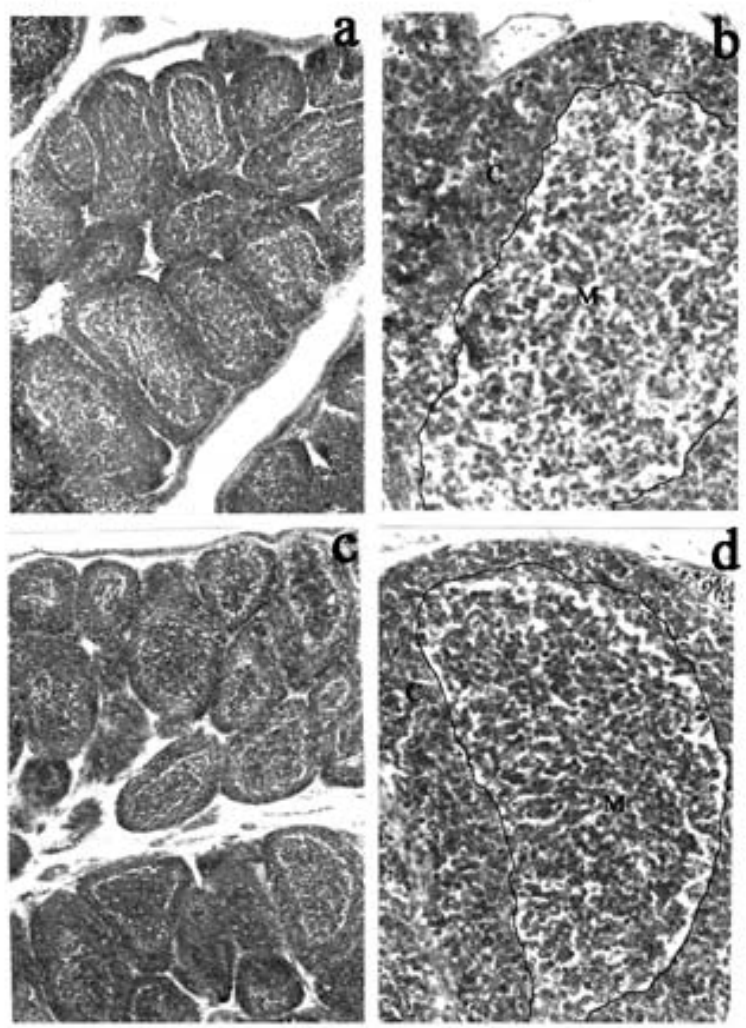

Figure 3. The structure of bursal compartments in vaccinated chickens is well preserved, although the follicles are smaller $(c, d)$. Control $(a, b)$ and vaccinated $(c, d)$ chickens. Original magnification 10x (a, c) and 40x (b, d) 
Acta Veterinaria (Beograd), Vol. 58. No. 1, 3-16, 2008.

Miljković Biljana et al.: Changes in lymphatic organs of layer chickens following

vaccination against Marek's disease: histological and stereological analysis

Table 1. Changes in the compartments of the bursa of Fabricius in vaccinated and control chickens obtained by the stereological method

\begin{tabular}{|l|c|c|}
\hline \multirow{2}{*}{ Parameters } & \multicolumn{2}{|c|}{ Experimental groups } \\
\cline { 2 - 3 } & Control & Vaccinated \\
\hline \hline Volume $\left(\mathrm{mm}^{3}\right)$ & & $0.19 \pm 0.01^{*}$ \\
Follicles & $0.26 \pm 0.02$ & $0.103 \pm 0.001$ \\
Follicular cortex & $0.115 \pm 0.005$ & $0.092 \pm 0.002^{*}$ \\
Follicular medulla & $0.138 \pm 0.004$ & $1.1: 1$ \\
Cortex/medulla & $0.8: 1$ & $16 \pm 0.5^{*}$ \\
\hline Numerical density (mm-3) & $10 \pm 0.2$ & $6.8 \pm 0.6$ \\
Follicles x 10-3 & & $18 \pm 0.09^{*}$ \\
Lymphocytes x 10-3 & $8.5 \pm 0.5$ & \\
Follicular cortex & $16 \pm 0.8$ & $43 \pm 3^{*}$ \\
Follicular medulla & & $3.2 \pm 0.3^{*}$ \\
Follicles & $32 \pm 2$ & $13.0 \pm 0.04^{*}$ \\
Cells & & \\
Follicular cortex & $5.0 \pm 0.5$ & \\
Follicular medulla & $10.0 \pm 0.2$ & \\
\hline
\end{tabular}

Volumes of the follicles, follicular cortex and medulla represent parts of bursal volume occupied with the analyzed structures. Total number of the follicles and cells within the cortex and medulla was calculated from the numerical density of thymocytes and absolute volume of the analyzed structures. Numerical density (NV) of the follicles and lymphocytes in the follicular cortex and medulla, expressed as number of thymocytes per volume unit of test area. The results are presented as mean values $\pm S D, n$ $=10{ }^{*} \mathrm{p}<0.05 ;$ vs. control.

\section{Thymus}

Analysis of thymus sections demonstrated that vaccination induces constriction of the thymus cortex with scant cell numbers (Figure 4). Considering the importance of thymus compartments in the process of thymocyte differentiation, we investigated whether application against Marek's disease evoked morphometrical changes in the thymus compartments. Our results showed that the vaccine reduces the thymus volume (Figure 1), as well as the volume of the thymic cortex and medulla. In addition, numerical density and number of cells in the thymic cortex and medulla and total number of thymocytes were decreased, too (Table 2). 
Table 2. Changes in the thymic compartments volume, number and the numerical density of thymocytes in the vaccinated and control chickens

\begin{tabular}{|c|c|c|}
\hline \multirow{2}{*}{ Parameters } & \multicolumn{2}{|c|}{ Experimental groups } \\
\hline & Control & Vaccinated \\
\hline Absolute number of thymocytes $\times 10^{6}$ & $16.5 \pm 0.6$ & $3.00 \pm 0.5^{\star \star *}$ \\
\hline Cortex & & \\
\hline Absolute volume $\left(\mathrm{cm}^{3}\right)$ & $0.29 \pm 0.05$ & $0.14 \pm 0.04^{* *}$ \\
\hline Number of thymocytes (x 106) & $14.5 \pm 0.1$ & $3.6 \pm 0.3^{\star \star}$ \\
\hline $\begin{array}{l}\text { Numerical density of thymocytes } \\
\left(\times 10^{-3}\right)\end{array}$ & $0.50 \pm 0.02$ & $0.37 \pm 0.01^{\star}$ \\
\hline \multicolumn{3}{|l|}{ Medulla } \\
\hline Absolute volume $\left(\mathrm{cm}^{3}\right)$ & $0.13 \pm 0.03$ & $0.07 \pm 0.01^{* *}$ \\
\hline Number of thymocytes (x 106) & $3.9 \pm 0.1$ & $1.54 \pm 0.02^{* *}$ \\
\hline $\begin{array}{l}\text { Numerical density of thymocytes } \\
\left(\times 10^{-3}\right)\end{array}$ & $0.30 \pm 0.004$ & $0.22 \pm 0.02^{*}$ \\
\hline \multicolumn{3}{|l|}{ Interlobular connective tissue } \\
\hline Absolute volume $\left(\mathrm{cm}^{3}\right)$ & $0.03 \pm 0.002$ & $0.01 \pm 0.001$ \\
\hline
\end{tabular}

Volumes of the cortex, medulla and interlobular connective tissue represent parts of tissue volume occupied with the analyzed structure. Total number of the thymocytes in the cortex and medulla was calculated from the numerical density and the absolute volume of the analyzed structure. Numerical density (NV) of the thymocytes in the outer cortex, deep cortex and medulla is expressed as number of thymocytes per volume unit of test area. The results are presented as mean values $\pm S D, n=10$. ${ }^{* \star *} p<0.001 ;{ }^{* \star} p<0.01 ;{ }^{*} p<0.05 ;$ vs.control

\section{Spleen}

Histological analysis showed that vaccination induces visible changes only in the spleen follicles (Figure 5). Namely, it raises their diameter, number and volume (Table 3).

Table 3 Changes in the volume of spleen lymphocytic follicles, their diameter and numerical density in the vaccinated and control chickens

\begin{tabular}{|l|c|c|}
\hline \multirow{2}{*}{ Parameters } & \multicolumn{2}{|c|}{ Experimental groups } \\
\cline { 2 - 3 } & Control & Vaccinated \\
\hline Follicles & & $230 \pm 15^{\star \star}$ \\
Diameter $(\mu \mathrm{m})$ & $76 \pm 6$ & $0.051 \pm 0.004^{\star \star}$ \\
Volume $\left(\mathrm{mm}^{3}\right)$ & $0.027 \pm 0.001$ & $1.65 \pm 0.2^{\star}$ \\
Numerical density $\times 10^{-3}$ & $1.1 \pm 0.15$ & \\
\hline
\end{tabular}

The results are presented as mean values $\pm S D, n=10 .{ }^{* *} p<0.01$; ${ }^{*} p<0.05$; vs.control 


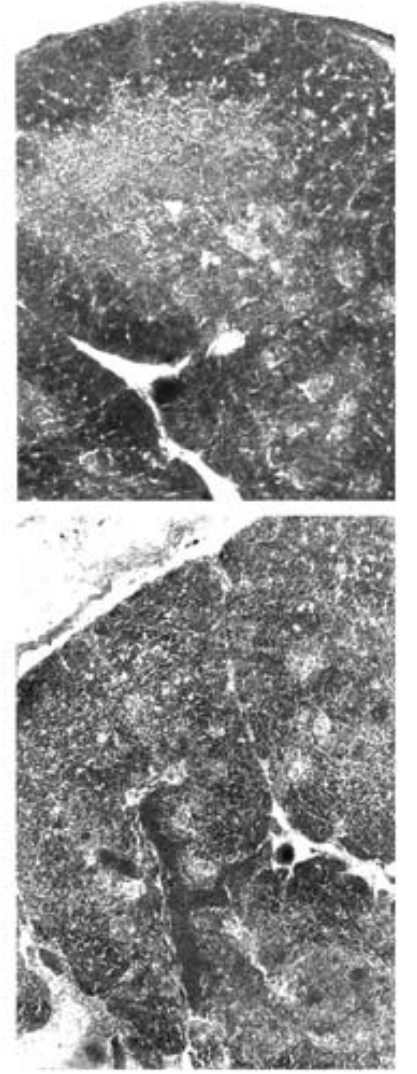

a

b

Figure 4. The thymus of the chickens vaccinated against Marek's disease (b) and control animals. Original magnification $10 x$

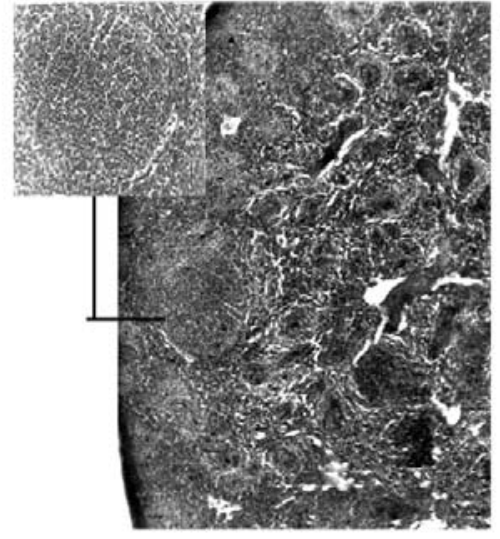

a

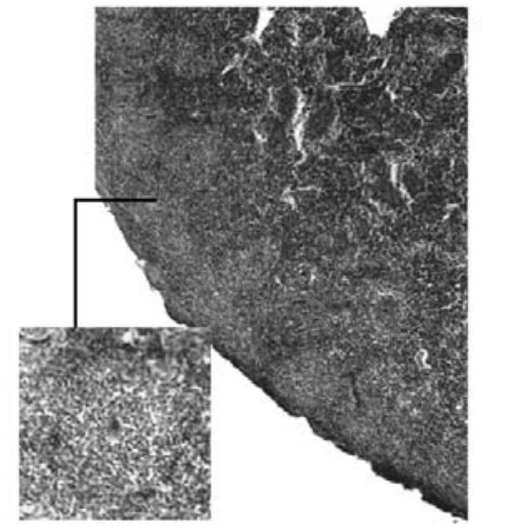

Figure 5. The spleen of vaccinated (a) and control (b) chickens. Original magnification 10x, and 40x (insert: lymphocytic follicles)

\section{DISCUSSION}

The aim of this study was to examine the changes in the lymphatic organs of vaccinated layer chickens with bivalent cell-associated Marek's disease vaccine. Our results revealed that this vaccine is immunosuppressive to commercial chickens, as evidenced by reduction of relative bursal and thymic weights, thymic index of damage, as well as B-cell and T-cell numbers. In agreement with our results are the findings of a mild depletion of $\mathrm{T}$ - and $\mathrm{B}$-lymphocytes after vaccination by other authors (Lee et al., 1999; Islam et al., 2002). Considering that the primary cell targets of MDV are the lymphocytes, and that the early effects are 
mainly seen in lymphatic organs such as the bursa of Fabricius, thymus and spleen (Venugopal and Payne, 1995; Calnek et al., 1998; Calnek, 2001), the results obtained in this study were to be expected. In addition, MDV-induced immunosuppression, including both the humoral and cell-mediated immunity, most likely associated with lymphopaenia due to cytolysis of $B$ and $T$ lymphocytes, (Calnek et al., 1998) is in line with the reduction of the cell number in the thymus and bursal follicular cortex. A transient depletion of B-lymphocyte activity of varying intensity has also been observed following the vaccination with bivalent (HVT + SB-1) or MDV serotype 1 (Rispens) vaccines (Friedman et al., 1992). Consequences of this immunosuppression may be linked with the reduced resistance to concurrent infection (Biggs et al., 1968; Abbassi et al., 1999, 2000), but the extent of immunosuppression varies according to several host resistance factors and the virus pathotype (Calnek et al., 1998; Baigent and Davison, 1999).

The vaccine against Marek's disease increases the number of bursal lymphatic follicles, while it reduces their volume and diameter, as a consequence of the follicular medulla reduction. Interestingly, this vaccine reduces the cell number in the follicular cortex and increases their number in the medulla. Separated maturation of B cells in the follicular cortex and medulla (Sayegh et al., 2000), rapid proliferation and gene conversion of the cortical B-cells (Reynaud et al., 1987; Masteller et al., 1995), and emigration of the cells predominantly directly from the cortical population to the periphery. Paramithiotis and Ratcliffe, 1994 support changes notified in the follicular cortex. In addition, the rapid cell proliferation, presumably due to selective expression of a functional B-cell receptor, may be the reason for the cell loss by apoptosis in this dynamic structure of bursa follicles (Sayegh et al., 1999; 2000). On the other hand, the changes in the follicular medulla may be explained by the medullar communication to the gut lumen via the lumen of the bursa, through specialized follicle-associated epithelium, which has the ability to transfer particulate matter from the lumen into the medulla (Sorvari et al., 1975) and most likely has an antigen-presenting function (Sorvari et al., 1997). The extent to which this may be involved in the generation of immune response is not clear.

Our results showed that vaccination reduces the thymus mass, as well as the volume of the thymic cortex and medulla, and significantly damages the thymus. In addition, it decreases the absolute number of thymocytes, and the numerical density and the number of the cells in the thymic cortex and medulla. The reduction of thymic weight was also described in MDV challenged chickens (Calnek et al., 1998) and a direct correlation between the degree of thymic/bursal atrophy, following MDV infection, and the virulence or pathotype of virus strains has been reported (Calnek et al., 1998). These results are accordant with results of Morimura and his collaborates (1996), who described thymic atrophy as a consequence of massive CD4+CD8+ thymocyte apoptosis and reduction in circulating CD4+ lymphocytes.

Finally, considering the cell number decrease in the thymus and bursa cortex it is to be expected that vaccination suppresses specific immune response in the spleen. However, the increased number and diameter of lymphocytic follicles in the spleen indicates that vaccination against Marek's disease has no 
effect on specific immune responses. This is consistent with the observation that vaccinal HVT failed to affect humoral antibody responses (Reddy et al., 1996). A similar result has been reported following vaccination with vaccine serotype 2 (Calnek et al., 1979).

The results obtained in this study suggest that the vaccinal Marek virus induced a decrease of the cell number in the bursal cortex and, especially, in the thymus. This most likely consequently increased the emigration of cells to the periphery, or cell lyses. On the other side, although vaccination has suppressive effects on the $B$ and $T$ cell numbers, it has no effect on the specific immune response.

Abbreviations: Marek's disease - MD; Marek's disease virus - MDV; Herpes virus turkey - HVT

Address for correspondence:

Mileva Mićić, Ph D

University of Belgrade - Institute for Medical Research

Department of Experimental Pathology and Cytology

Dr Subotića 4, PO Box 102

11129 Belgrade, Serbia

E-mail: evica@imi.bg.ac.yu

\section{REFERENCES}

1. Abbassi H, Coudert F, Cherel Y, Dambrine G, Brugere-Picoux J, Naciri M, 1999, Renal cryptosporidiosis (Cryptosporidium bailey) in specific-pathogen-free chickens experimentally coinfected, with Marek's disease virus, Avian Dis, 43, 738-44.

2. Abbassi H, Coudert F, Dambrine G, Cherel Y, Naciri M, 2000, Effect of Cryptosporidium baileyi in specific pathogen free chickens vaccinated (CVI988/Rispens) and challenged with HPRS-16 strain of Marek's disease virus, Avian Pathol, 29, 623-34.

3. Adidinger HK, Calnek BW, 1973, Pathogenesis of Marek's disease: Early distribution of virus and viral antigens infected chickens, J Nat Cancer Institute, 50, 1287-98.

4. Bacon LD, Witter RL, 1993, Influence of B-haplotype on the relative efficacy of Marek's disease vaccines of different serotypes, Avian Dis, 37, 53-9.

5. Bacon LD, Witter RL, 1994a. B haplotype influence on the relative efficacy of Marek's disease vaccines in commercial chickens, Poultry Sci, 73, 481-7.

6. Bacon LD, Witter RL, 1994b, Serotype specificity of B-haplotype influence on the relative efficacy of Marek's disease vaccines, Avian Dis, 38, 65-71.

7. Baigent SJ, Davison TF, 1999, Development and composition of lymphoid lesions in the spleens of Marek's disease virus-infected chickens: association with virus spread and the pathogenesis of Marek's disease. Avian Pathology, 28, 287-300.

8. Barrow DA, Burgess CS, Baigent JS, Howes K, Nair KV, 2003, Infection of macrophages by a lymphotropic herpesvirus: a new tropism for Marek's disease virus, J Gen Virol, 84, 2635-45.

9. Beasley JN, Patterson LT, MeWade DH, 1970, Trensmission of Marek's disease bay poultry house dust and chickens dander, Am J Vet Res, 31, 339-44.

10. Biggs PM, Long PL, Kenzy SG, Rootes DG, 1968, Relationship between Marek's disease and coccidiosis. II. The effect of Marek's disease on the susceptibility of chickens to coccidial infection, Veterinary Record, 83, 284-89.

11. Brown CA, Baigent JS, Smith PL, Chattoo JP, Petherbridge, Hawes P, Allday JM, Nair V, 2006 , Interaction of MEQ protein and C/terminal-binding protein is critical for induction of lymphomas by Marek's disease virus, PNAS, 103, 1687-92. 
12. Calnek BW, 2001, Pathogenesis of Marek's disease virus infection, Curr Top Microbiol Immunol, 255, 25-55.

13. Calnek BW, Carlisle JC, Fabricant J, Murthy KK, Schat KA, 1979, Comparative pathogenesis studies with oncogenic and nononcogenic Marek's disease viruses and turkey herpesvirus, Am $J$ Vet Res, 40, 541-8.

14. Calnek BW, Harris RW, Buscaglia C, Schat KA, Lucio B, 1998, Relationship between the immunosuppressive potential and the pathotype of Marek's disease virus isolates, Avian Diseases, 42, 124-32.

15. Calnek BW, Schat KA, Ross LJ, Chen Cl, 1984, Futher characterization of Marek's disease virus infected lymphocytes. II. In vitro infection, Int J Cancer, 33, 339-406.

16. Churchill AE, Biggs PM, 1967, Agent of Marek's disease in tissue culture, Nature, 215, 528-30.

17. Friedman A, Shalem-Meilin E, Heller ED, 1992, Marek's disease vaccines cause temporary Blymhocyte dysfunction and reduced resistance to infection in chicks, Avian Pathol, 21, 621-31.

18. Fynan EF, Webster RG, Fuller DH, Haynes JR, Santoro JC, Robinson HL, 1995, DNA vaccines : a novel approach to Immunization, Int J Immunopharmacol, 17, 79-83.

19. Islam AFMF, Walkden-Brown SW, Wong CW, Groves PJ, Burgess SK, Arzey KE, Young PL, 2001, Influence of vaccine deposition site on post-vaccinal viraemia and vaccine efficacy in broiler chickens following in ovo vaccination against Marek's disease, Avian Pathol, 30, 527-35.

20. Islam FMFA, Wong WC, Walkden-Brown W S, Colditz Gl, Arzey EK, Groves JP, 2002, Immunosuppressive effects of Marek's disease virus (MDV) and herpesvirus of turkeys (HVT) in broiler chickens and the protective effect of HVT vaccination against MDV challenge Groves, Avian Pathol, 31, 449- 61

21. Kalisnik M, 1985, Temelji stereologije. In: Acta Stereol, Vol. 4, Ljubljana.

22. Lee LF, Sharma JM, Nazerian K, Witter RL, 1978, Suppression and enhancement of mitogen response in chickens infected with Marek's disease virus and the herpesvirus of turkeys, Infect Immun, 21, 474-9.

23. Lee SI, Ohashi K, Morimura T, Sugimoto C, Onuma M, 1999, Re-isolation of Marek's disease virus from T cell subsets of vaccinated and non-vaccinated chickens, Arch Virol, 144, 45-54.

24. Masteller EL, Lee KP, Carlson LM, Thompson CB, 1995, Expression of sialyl Lewis (x) and Lewis (x) defines distinct stages of chicken B cell maturation, $J$ Immunol, 155, 5550-6.

25. Mićić M, Miljković B, Stamatović S, Šaban A, Nedeljković J, Mitevski D, Knežević M, 2000 Morphometrical analysis of lymphoid follicles of the chicken spleen vaccinated against Marek's disease, Mac Vet Rew, 29, 39-45.

26. Morimura T, Ohashi k, Kon Y, Hattori H, Sugimoto C, Onuma M, 1999, Apoptosis and CD8-downregulation in the thymus of chickens infected with Marek's disease virus, Arch Virol, 141, 22439.

27. Omar AR, Schat KA, 1996, Syngeneic Marek's disease virus (MDV)-specific cell-mediated immune responses against immediate early, late, and unique MDV proteins, Virology, 222, 87-99.

28. Paramithiotis $E$, Ratcliffe $M J, 1994$, B cell emigration directly from the cortex of lymphoid follicles in the bursa of Fabricius, Eur J Immunol, 24, 458-63.

29. Powell PC, Lombardini F, 1986, Isolation of very virulent pathotypes of Marek's disease virus from vaccinated chickens in Europe, Vet Rec, 118, 688-91.

30. Purchase HG, Okazaki W, Burmester BR, 1971, Field trials with the herpesvirus of turkeys (HVT) strain FC126 as a vaccine against Marek's disease, Poultry Sci, 50, 775-83.

31. Reddy SK, Suresh M, Karaca K, Sharma JM, McMillen J, Schwartz RD, 1996, Antigen-specific lymphoproliferative responses to tetanus toxoid: a means for the evaluation of Marek's disease virus-induced immunosuppression in chickens, Vaccine, 14, 1695-702.

32. Reynaud CA, Anquez V, Grimal H, Weill JC, 1987, A hyperconversion mechanism generates the chicken light chain preimmune repertoire, Cell, 48, 379-88.

33. Sayegh CE, Demaries SL, Pike KA, Friedman JE, Ratcliffe MJ, 2000, The chicken B cell receptor complex and its role in avian B cell Development, Immunol Rev, 2000, 175, 187-200.

34. Sayegh CE, Drury G, Ratcliffe MJH, 1999, Efficient antibody diversification by gene conversion in vivo in the absence of selection for V (D) J-encoded determinants, EMBO J, 18, 6319-28. 
35. Sonoda K, Sakaguchi M, Okamura H, Yokogawa K, Tokunaga E, Tokiyoshi S, Kawaguchi Y, Hirai K, 2000, Development of an Effective Polyvalent Vaccine against both Marek's and Newcastle Diseases Based on Recombinant Marek's Disease Virus Type 1 in Commercial Chickens with Maternal Antibodies, J Virol, 74, 3217-26.

36. Sorvari R, Sorvari TE, 1997, Bursa Fabricii as a peripheral lymphoid organ, Immunology, 32, 499505.

37. Sorvari T, Sorvari R, Ruotsalainen P, Toivanen A, Toivanen P, 1975, Uptake of environmental antigens by the bursa of Fabricius, Nature, 253, 217-9.

38. Tischer KB, Schumacher D, Beer M, Beyer J, Teifke PJ, Osterrieder K, Wink K, Zelnik V, Fehler F, Osterrieder N, 2002, A DNA vaccine containing an infectious Marek's disease virus genome can confer protection against tumorigenic Marek's disease in chickens, J Gen Virol, 83, 236776.

39. Venugopal K, Payne LN, 1995, Molecular pathogenesis of Marek's disease-recent developments Avian Pathol, 24, 597-609.

40. Weibel ER, 1979, Stereological methods, In: Practical Methods for Biological Morphometry, Academic Press, London, 1-415.

41. Witter RL, 1998, The changing landscape of Marek's disease, Avian Pathol, 27, S46-S53.

42. Witter RL, 2001, Marek's disease vaccines - past, present and future [chicken versus virus - a battle of the centuries], Current Progress on Marek's Disease Research, In: Schat AK, Morgan MR, Parcells SM, Spencer LJ, editors, American Association of Avian Pathologists, Kennett Square, PA, USA.

43. Witter RL, Lee $L F, 1984$, Polyvalent Marek's disease vaccines: safety, efficacy and protective synergism in chickens with maternal antibodies, Avian Pathol, 13, 75-92.

44. Witter RL, Lee LF, Fadly AM, 1995, Characteristics of CVI988/Rispens and R2/23, two prototype vaccine strains of serotype 1 Marek's disease virus, Avian Dis, 39, 269-84.

45. Witter RL, Sharma JM, Lee LF, Nazerian K, 1984, Field trials to test the efficiacy of polyvalent Marek's disease vaccines in broilers, Avian Dis, 28, 44-60.

\title{
PROMENE U LIMFATIČNIM ORGANIMA KOMERCIJALNIH PILIĆA NAKON VAKCINACIJE PROTIV MAREKOVE BOLESTI: HISTOLOŠKA I STEREOLOŠKA ANALIZA
}

\author{
MILJKOVIĆ BILJANA, RAKIN ANA, AŠANIN RUŽICA, DIMITRIJEVIĆ LJILJANA \\ i MIĆIĆ MILEVA
}

\section{SADRŽAJ}

Cilj ovih ispitivanja su bile histomorfometrijske karakteristike timusa, burze Fabricii i slezine pilića vakcinisanih protiv Marekove bolesti. Za istraživanja su korišćeni jednodnevni pilići lake hibridne linije, gajeni u standardnim uslovima. Pilići su vakcinisani 5. dana od izleganja, bivalentnom vakcinom protiv Marekove bolesti (PFU 2000 po dozi). Trinaestog dana od izleganja kontrolni i vakcinisani pilići su žrtvovani, uzeti su im timus, burza Fabricii i slezina koji su pripremljeni za svetlosno mikroskopsku analizu. Za analizu su korišćeni serijski preseci limfatičnih organa, bojeni metodom hematoksilin-eozin. Dobijeni rezultati su ukazali da vakcinacija protiv Marekove bolesti dovodi do smanjenja relativne mase ti- 

vaccination against Marek's disease: histological and stereological analysis

musa, burze i slezine, kao i povećanja indeksa oštećenja timusa i slezine. Takođe je ustanovjleno da vakcinacija dovodi do promena morfometrijskih parametara u limfatičnim organima. U burzi Fabricii je uočeno značajno smanjenje dijametra i zapremine limfocitnih folikula, zapremine medule folikula i broja ćelija u korteksu folikula. U timusu vakcinacija dovodi do redukcije zapremine timusa i apsolutnog broja timocita. Međutim, vakcinacija protiv Marekove bolesti u slezini dovodi do povećanja dijametra limfocitnih folikula, kao i do povećanja njihovog broja i zapremine. Rezultati ove studije su ukazali da vakcinacija pilića protiv Marekove bolesti, iako redukuje broj T i B limfocita, indukuje razvoj imunskog odgovora. 